\title{
BAHASA ARAB DAN METODE PENGAJARANNYA
}

\section{Ana Achoita*}

\begin{abstract}
:
Arabic is one language that has touched various world realms. Along with the development of the age, requires us to always move to follow it so that the method of learning arabic and its innovation will be a challenge. All methods are good, but the choice of a method is determined by many factors, including: teaching goals, background, student language, student age, available time, teacher readiness, and sociocultural factors.
\end{abstract}

*Ana Achoita adalah Dosen Prodi PAI Sekolah Tinggi Ilmu Tarbiyah Makhdum Ibrahim Tuban

\section{A. PENDAHULUAN}

Bahasa Arab merupakan salah satu bahasa yang telah menyentuh berbagai ranah dunia. Selain sebagai bahasa media ajaran islam, bahasa Arab juga telah berjasa dalam menjunjung tinggi sains dan teknologi, memperkaya khazanah budaya nasional dan media perubahan politik internasional yang semakin menampakkan perananya dewasa ini. Sehingga bahasa Arab mengalami perkembangan yang sangat pesat.

Seiring dengan berkembangnya zaman dalam berbagai bidang terutama ilmu pengetahuan dan teknologi yang melaju dengan pesat menuntut kita untuk selalu bergerak mengikutinya, informasi apapun dapat kita peroleh dengan mudah dan cepat, penguasaan bahasa asing juga akan menambah wawasan dan informasi yang cepat dan akurat, tidak akan terbujuk oleh orang lain.

Salah satu usaha untuk meningkatkan kualitas sumber daya manusia adalah melalui pembelajaran di sekolah, terdiri dari beberapa komponen yang saling berinteraksi. 
Komponen-komponen tersebut meliputi: guru, materi pelajaran dan siswa. Komponen tersebut saling berinteraksi sehingga tujuan yang telah direncanakan dapat tercapai dengan baik.

Bahasa yang digunakan pendidik dalam rangka transfer ilmu pengetahuan mempengaruhi daya tangkap materi yang diterima oleh siswa, semakin mudah dan sederhana bahasa yang digunakan maka akan semakin maksimal penyampaian materinya. Adapun metode pembelajaran Bahasa Arab dan inovasinya akan menjadi tantangan tersendiri bagi setiap guru bahasa Arab. Oleh karena itu pembelajaran bahasa arab juga menuntut kecerdasan setiap guru untuk memahami aspek yang berkaitan dengan hasil pembelajaran. Yakni dengan menciptakan teknik-teknik baru dalam pembelajaran bahasa arab agar siswa menjadi lebih aktif, terampil, mampu menguasai dan mahir dalam bahasa arab.

\section{B. PENGERTIAN BAHASA ARAB}

Menurut Ali Ridho (1986:54) bahasa adalah "sistem lambang bunyi yang arbitrer, yang dipergunakan oleh para anggota suatu masyarakat untuk bekerja sama, berinteraksi, dan mengidentifikasikan diri, percakapan (perkataan) yang baik, tingkah laku yang baik, sopan santun, baik budinya, menunjukkan bangsa, budi bahasa atau perangai serta tutur kata menunjukkan sifat dan tabiat seseorang (baik buruk kelakuan menunjukkan tinggi rendah asal atau keturunan)". Arab adalah "nama bangsa di Jazirah Arab dan timur tengah".

Pakar ilmu Ushul, lughah (bahasa) adalah setiap lafadz (kata) yang dibuat untuk menunjukkan makna tertentu, cara mengetahui lughah adalah melalui periwayatan (Ibnu Khalil, 2000:115). Sedangkan al-Ghalayaini (2005:7) mendefinisikan bahasa dengan: alfazh yu'abbir kullu qaum 'an maqasidihim (berbagai kata yang digunakan masyarakat untuk mengungkapkan berbagai maksud mereka).

Dari konteks ini, bahasa Arab didefinisikan dengan: 


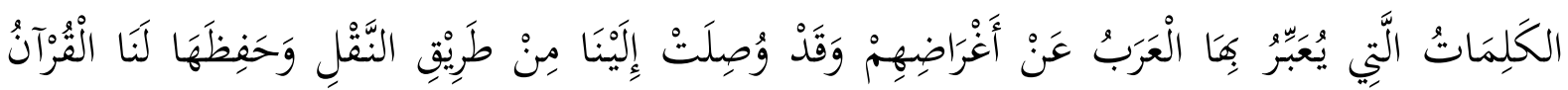

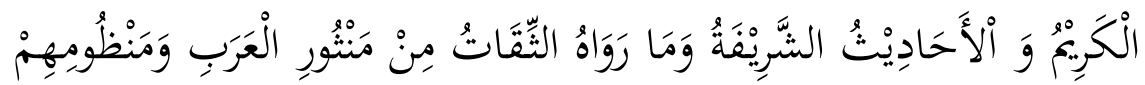

Berbagai kata yang digunakan orang-orang Arab untuk mengungkapkan berbagai maksud atau tujuan mereka, disampaikan pada kita dengan jalan menukil/ transfer/ riwayat, dihimpun dan dijaga kepada kita oleh al-Quran al-Karim dan hadits-hadits mulia, dan berbagai riwayat terpercaya berupa prosa-prosa dan syair-syair Arab (AlGhalayaini, 2005:7)

Jadi dapat kami ambil kesimpulan bahwa Bahasa Arab adalah tutur kata yang digunakan oleh bangsa di jazirah arab dan timur tengah.

\section{METODE PEMBELAJARAN BAHASA ARAB}

Effendy (2005:29) menyatakan bahwa dalam hal metode pembelajaran bahasa Arab, setiap metode memiliki landasan-landasan teoritis dan empiris. Secara skeptis bisa dikatakan bahwa tampaknya semua metode ada baiknya. Pada kenyatannya, hingga saat ini, tidak ada metode (yang paling kuno sekalipun) yang mati atau ditinggalkan sama sekali, dan tidak ada pula metode yang paling dominan sepanjang waktu atau disemua tempat. Ini terjadi karena pemilihan suatu metode ditentukan oleh banyak faktor, antara lain: tujuan pengajaran, latar belakang, bahasa pelajar, usia pelajar, waktu yang tersedia, kesiapan guru, dan faktor sosiokultural.

Menurut Khouly (1986:52) ada beberapa metode pembelajaran bahasa Arab, diantaranya:

1. Metode Gramatika Terjemah (طريقة القواعد والترجمة)

Metode ini berdasarkan asumsi bahwa ada satu "logika semesta" yang merupakan dasar semua bahasa di dunia ini, dan bahwa tatabahasa merupakan bagian 
dari filsafat dan logika. Belajar bahasa dengan demikian dapat memperkuat kemampuan berfikir logis, memecahkan masalah, dan menghafal.

Para pelajar bahasa dengan metode ini didorong untuk menghafal teks-teks klasik berbahasa asing dan terjemahannya dalam bahasa pelajar, terutama teks-teks yang bernilai sastra tinggi, walaupun dalam teks itu sering kali terdapat struktur kalimat yang rumit dan kosakata atau ungkapan yang sudah tidak terpakai.

Adapun langka-langkah penyajian pada umumnya sebagai berikut:

a. Guru memulai pelajaran dengan menjelaskan definisi butir-butir tatabahasa kemudian memberikan contoh-contohnya. Buku teks yang dipakai memang menggunakan metode deduktif.

b. Guru menuntuk siswa menghafalkan daftar kosakata dan terjemhannya atau meminta siswa mendemonstrasikan hafalan kosakata yang telah diajarkan sebelumnya.

c. Guru meminta siswa membuka buku teks bacaan kemudian menuntun siswa memahami isi bacaan dengan menerjemahkannya kata perkata atau kalimat perkalimat atau guru meminta siswa membaca dalam hati kemudian mencoba menerjemahkannya perkata atau kalimat; guru membetulak terjemahn yang salah dan menerangkan bebewrapa segi ketatabahasaan (nahwu-shorof) dan keindahan bahasannya (balaghah). Pada waktu lain guru juga meminta siswa melakukan analisis tatabahasa (meng-i'rob)

2. Metode Langsung (الطريقة المباشرة)

Metode ini dikembangkan atas dasar asumsi bahwa proses belajar bahasa kedua atau bahasa asing sama dengan belajar bahasa ibu, yaitu dengan penggunaan 
bahasa secara langsung dan intensif dalam komunikasi, dan dengan menyimak dan berbicara. Sedangkan mengarang dan membaca dikembangkan kemudian.

Langkah-langkah penyajian dalam metode ini bisa berfariasi, namun secara umum adalah sebagai berikut:

a. Guru memulai penyajian materi secara lisan, mengucapkan satu kata dengan menunjuk bendanya atau gambar benda itu, memeragakan sebuah gerakan atau mimik wajah. Pelajar menirukan berkali-kali sampai benar pelafalannya dan faham maknanya

b. Latihan berikutnya berupa tanya jawab dengan kata tanya "ma, hal, aina" dan sebagainya sesuai dengan tingkat kesulitan pelajaran, berkaitan dengan kata-kata yang telah disajikan. Model interaksi bervariasi biasanya dimulai dengan klasikal, kemudian kelompok, dan akhirnya individual baik guru-siswa maupun antar siswa

c. Setelah guru yakin bahwa siswa menguasai materi yang disajikan, baik dalam pelafalan maupun pemakahan makna, siswa diminta membuka buku teks. Guru memberikan contoh bacaan yang benar kemudian siswa diminta membaca secara bergantian

d. Kegiatan berikutnya dalah menjawab secara lisan pertanyaan atau latihan yang ada dalam buku, dilanjutkan dengan mengerjaknnya secara tertulis

e. Bacaan umu yang sesuai dengan tingkatan siswa diberikan sebagai tambahan, misalnya berupa cerita humor, cerita yang mengandiung hikmah dan bacaan yang mengandung ungkapan-ungkapan indah. Karena pendek dan menarik, biasanya siswa menghafalnya diluar kepala

f. Tatabahasa diberikan pada tingkat tertentu secara induktif

3. Metode Membaca (طريقة القراءة) 
Tujuan metode ini adalah agar pelajar mampu memahami teks ilmiah untuk keperluan studi mereka. Langkah-langkah penyajian metode ini adalah:

a. Pelajaran dimulai dengan pemberian kosa kata dan istilah yang dianggap sulit dan penjelasan maknanya dengan definisi dan contoh dalam kalimat

b. Siswa membaca teks bacaan secara diam selama kurang lebih 25 menit

c. Diskusi mengenai isi bacaan yang dapat berupa tanya jawab dengan menggunakan bahasa ibu pelajar

d. Pembicaraan mengenai tatabahasa secara singkat kalau dianggap perlu

e. Pembahasan kosakata yang belum dibahas sebelumnya

f. Mengerjakan tugas-tugas yang ada dalam buku suplemen, yaitu menjawab pertanyaan tentang isi bacaan, latihan menulis terbimbing, $\mathrm{dsb}$

g. Bahan bacaan perluasan dipelajari di rumah dan dilaporkan hasilnya pada pertemuan berikutnya

4. Metode Audiolingual (الطريقة السمعية الشفهية)

Metode audiolingual didasarkan atas beberapa asumsi, antara lain bahwa bahasa itu pertama-tama adalah ujaran. Oleh karena itu pengajaran bahasa harus dimulai dengan memperdengarkan bunyi-bunyi bahasa dalam bentuk kata atau kalimat kemudian mengucapkannya, sebelum pelajaran membaca dan menulis. Selain itu pelajaran bahasa harus diisi dengan kegiatan berbahasa bukan kegiatan mempelajari kaidah-kaidah berbahasa. Urutan penyajiannya adalah menyimak dan berbicara baru kemudian membaca dan menulis.

Langkah-langkah penyajiannya adalah:

a. Penyajian dialog atau bacaan pendek, dengan cara guru membacanya berulang kali, dan pelajar menyimak tanpa melihat teks 
b. Peniruan dan penghafalan dialog atau bacaan pendek dengan teknik menirukan bacaan guru kalimat perkalimat secara klasikal sambil menghafalakn kalimatkalimat tersebut

c. Penyajian pola-pola kalimat yang terdapat dalam dialog atau bacaan pendek, terutama yang dianggap sukar, karena terdapat struktur atau ungkapan yang berbeda dengan struktur dalam bahasa ibu pelajar. Ini dilakukan dengan teknik drill

d. Dramatisasi dialog atau bacaan pendek yang sudah dilatihkan. Para pelajar mendramatisasikan dialog yang sudah dihafalkan di depan kelas secara bergantian.

e. Pembentukan kalimat-kalimat lain yang sesuai dengan pola-pola kalimat yang sudah dipelajari

5. Metode Komunikatif (الطريقة الاتصالية)

Metode komunikatif didasarkan atas asumsi bahwa setiap manusia memiliki kemampuan bawaan yang disebut alat pemerolehan bahasa. Kemampuan berbahasa bersifat kreatif dan lebih ditentukan oleh faktor internal. Tujuan pengajarannya ialah mengembangkan kompetensi pelajar berkomunikasi dengan bahasa target dalam konteks komunikatif yang sesungguhnya atau dalam situasi kehidupan yang nyata.

Langkah-langkah penyajianya antara lain;

a. Dialog pendek disajikan dengan didahului penjelasan tentang fungsi ungkapan dalam dialog itu dan situasi di mana dialog itu terjadi

b. Latihan pengucapan kalimat-kalimat pokok secara perorangan, kelompok atau klasikal 
c. Pertanyaan diajukan tentang isi dan situasi dalam dialog itu dialnjutkan pertanyaan serupa tetapi langsung mengenai situasi masing-masing pelajar. Di sini kegiatan komunikatif yang sebenarnya telah dimulai

d. Kelas membahas ungkapan-ungkapan komunikatif dalam dialog

e. Siswa diharapkan menarik sendiri kesimpulan tentang aturan tatabahasa yang termuat dalam dialog. Guru memfasilitasi dan meluruskan apabila terjadi kesalahan dan penyimpulan

f. Pelajar melakukan kegiatan menafsirkan dan menyatakan suatu maksud sebagai bagian dari latihan komunikasi yang lebih bebas dan tidak sepenuhnya berstruktur.

g. Pengajar melakukan evaluasi dengan mengambil sampel dari penampilan pelajar dalam kegiatan komunikasi bebas.

6. Metode Eklektik (الطريقة الانتقائية)

Metode ini didasarkan atas asumsi bahwa (1) tidak ada metode yang ideal karena masing-masing memiliki kekuatan dan kelemahan, (2) tidak ada satu metode yang cocok untuk semua tujuan, semua guru, semua siswa dan semua program pengajaran, (3) yang terpenting dalam pengajaran adalah memenuhi kebutuhan pelajar bukan memenuhi kebutuhan suatu metode, (4) setiap guru memiliki kewenangan dan kebebasan untuk memilih metode yang sesuai dengan kebutuhan pelajar.

Metode eklektik ini bisa menjadi ideal apabila didukung oleh penguasaan guru secara memadai terhadap berbagai macam metode sehingga dapat mengambil secara tepat sehi kekuatan setiap metode dan menyesuaikannya dengan kebutuahn kemudain menerapkannya secara proporsional. 


\section{POKOK-POKOK BAHASAN KEMAMPUAN BAHASA ARAB}

Di dalam setiap bahasa terdapat unsur-unsur yang dapat dilihat secara terpisah-pisah meskipun satu sama lain saling berhubungan dengan erat bahkan menyatu sehingga terbentuk sebuah fenomena yang bernama bahasa. Pokok-pokok komponen bahasa arab untuk madrasah meliputi unsur-unsur bahasa (bentuk kata/sharfiy, struktur kalimat dan kosakata) dan kegiatan berbahasa. Performansi dan kemampuan berbahasa juga bermacam-macam. Ada yang berbentuk lisan dan ada yang berbentuk tulisan. Ada yang bersifat reseptif (menyimak dan membaca) dan ada yang bersifat produktif (berbicara dan menulis) (Effendy, 2005:78).

Dalam metode pengajaran bahasa, pengajaran tata bahasa berfungsi sebagai penunjang tercapainya kemahiran berbahasa dan sarana untuk dapat menggunakan bahasa dengan benar dalam komunikasi. Sebagaimana yang diungkapkan Effendy (2005:85) bahwa pada dasarnya kegiatan pengajaran tata bahasa terdiri dari dua bagian, (a) pengenalan kaidahkaidah bahasa (al-nahwu dan al-sharf), dan (b) pemberihan latihan atau drill. Kedua bagian tersebut dapat dilaksanakan dengan dua cara, deduktif atau induktif.

a. Pengenalan Kaidah

Pengenalan kaidah dapat dilakukan dengan cara deduktif atau induktif.

(1) Cara Deduktif

Dimulai dengan pemberian kaidah yang harus dipahami dan dihafalkan, kemudian diberikan contoh-contoh. Setelah itu, siswa diberi kesempatan untuk melakukan latihan-latihan untuk menerapkan kaidah atau rumus yang telah diberikan.

Car ini mungkin lebih disenangi oleh sebagian pembelajar bahasa yang telah dewasa, karena dalam waktu singkat mereka telah dapat mengetahui kaidah-kaidah bahasa, dan dengan daya nalarnya mereka dapat mengaplikasikan kaidah-kaidah itu setiap kali diperlukan. 
Kelemahannya, pembelajar cenderung hanya menghafalkan kaidah dan kurang terlibat dalam proses pemahamannya. Akibatnya pembelajar kurang mampu menerapkan kaidah dalam praktek berbahasa yang sesungguhnya.

(2) Cara Induktif

Dilaksanakan dengan cara, guru pertama-tama menyajikan contoh-contoh (al amtsilah). Setelah mempelajari contoh-contoh yang diberikan, siswa dengan bimbingan guru menarik kesimpulan sendiri kaidah-kaidah bahasa berdasarkan contoh-contoh tersebut. Dengan cara ini, siswa secara aktif berpartisipasi dalam kegiatan pembelajaran, yakni dalam menyimpulkan kaidah-kaidah. Karena penyimpulan ini dilakukan setelah siswa mendapat latihan yang cukup, maka pengetahuan tentang kaidah itu benar-benar berfungsi sebagai penunjang ketrampilan berbahasa.

Yang dianggap sebagai kelemahan dari cara ini adalah banyaknya waktu yang diperluakn untuk memperkenalkan kaidah-kaidah baru, sehingga pelajar bahasa yang sudah dewasa biasanya kurang sabar.

Suatu hal yang harus dihindari dalam pengenalan kaidah, baik dengan cara deduktif maupun induktif, ialah kecenderungan berlama-lama dalam membahas kaidah-kaidah tanpa sempat melakukan latihan berbahasa itu sendiri, sehingga kegiatan di dalam kelas lebih menyerupai kegiatan analisis bahasa dari pada kegiatan berbahasa akibatnya pengetahuan tentang kaidah-kaidah itu hanya sebagai pengetahuan.

b. Latihan

(Drill)

Beberapa pendekatan dan metode mutakhir menekankan perlunya penyajian gramatikal fungsional (al-nahwu al-wazhi:fi) baik dari segi pilihan materi maupun cara penyajiannya. Yang ditekankan bukanlah penguasaan kaidah, apalagi sekedar 
menghafalkan definisinya melainkan kemampuan membuat kalimat-kalimat gramatikal. Oleh karena itu latihan yang diberikan berbentuk dril-dril pola kalimat. Ada 3 jenis latihan yang masing-masing bisa berdiri sendiri atau bisa merupakan satu urutan yang merupakan kesatuan, yakni:

(1) Latihan mekanis

(2) Latihan bermakna

(3) Latihan komuniukatif

Dengan urutan ini tidak berarti bahwa jenis latihan pertama harus diberikan dalam kurun waktu tertentu baru kemudian boleh dilanjutkan dengan jenis latihan kedua dan selanjutnya. Ketiga jenis latihan itu, bisa saja diberikan secara berurutan dalam satu jam pelajaran.

Penerapan ketiga jenis latihan ini adalah merupakan implementasi dari metode eklektik, yaitu gabungan antara metode audio lingual dan metode komunikatif. Seperti diketahui, metode audio lingual menekankan pada latihan mekanis, sedangkan metode komunikatif menekankan pada latihan komunikatif. Untuk menggabungkan keduanya dijembatani dengan latihan bermakna atau semi komunikatif.

(1) Latihan Mekanis

Pada dasarnya latihan ini bertujuan menanamkan kebiasaan dengan memberikan stimulus untuk mendapatkan respon yang benar. Latihan-latihan ini bisa diberikan secara lisan atau tertulis dan diintegrasikan dengan latihan ketrampilan berbicara dan menulis.

Ada bermacam-macam latihan mekanis, antara lain:

(a) Pengulangan sederhana, misalnya:

Stimulus : فتح المدرس كتابا 
فتح المدرس كتابا : Respon

(b) Penggantian sederhana, misalnya:

حامد يجب قميصا أبيض : Stimulus

Respon : حامد يحب قميصا أبيض

سروال: Stimulus

حامد يحب سروالا أبيض: Respon

(c) Penggantian berganda, misalnya:

Stimulus : ركب أحمد دراجة

Respon : ركب أحمد دراجة

Stimulus : محمود - سيارة

Respon ركب محمود سيارة

(d) Transformasi, misalnya:

Stimulus : سافر خالد إلى العاصمة

Respon : مافر 
Stimulus : فاطمة

Respon : مافرت فاطمة إلى العاصمة

(e) Penggabungan kalimat dengan penambahan isim al-maushu:l

قرأت كتابا - اشتريت كتابا بالأمس : Stimulus

قرأت الكتاب الذي اشتريته بالأمس : Respon

Stimulus : أركب الدراجة - أستعير الدراجة من صديقى

Respon أركب الدراجة التي أستعيرها من صديقي

Untuk melaksanakan latihan-latihan mekanis ini,sebaiknya guru memulai dengan memberikan contoh-contoh dan menunjukkan bagian mana yang harus diubah. Setelah jelas, guru tinggal memberikan aba-aba untuk melanjutkan substitusi atau transformasi dan seterusnya.

Untuk variasi, pelaksanaan dril di dalam kelas dapat dilakukan dengan beberapa cara, antara lain:

1) Guru sendiri yang membacakan atau memberikan stimulus dan murid diminta merespon.

2) Guru memutarkan tape-recorder dan menunjuk siswa untuk merespon satupersatu.

3) Guru meminta seorang siswa untuk mempersiapkan dan memimpin satu drill tentang pokok bahasan tertentu. 
4) Guru meminta para siswa melakukan drill secara berpasangan; seorang membacakan stimulus dan yang lain merespon, kemudian bertukar peran.

(2) Latihan Bermakna

Kalau latihan mekanis sepenuhnya bersifat manipulatif, karena kalimat yang diucapkan oleh siswa sama sekali tidak dihubungkan dengan konteks atau situasi, maka latihan bermakna ini sudah dihubungkan dengan konteks atau situasi yang sebenarnya oleh karena itu dapat dikatakan sebagai latihan semi-komunikatif.

Pemberian konteks dapat berupa:

1) Alat peraga: baik berupa benda-benda ilmiah maupun gambar-gambar, yang dipakai untuk memberikan makna pada kalimat-kalimat yang dilatihkan.

2) Situasi kelas: benda-benda yang ada di dalam kelas dapat dimanfaatkan untuk pemberian makna.

Di bawah ini contoh latihan dengan memakai situasi di dalam kelas sebagai konteksnya.

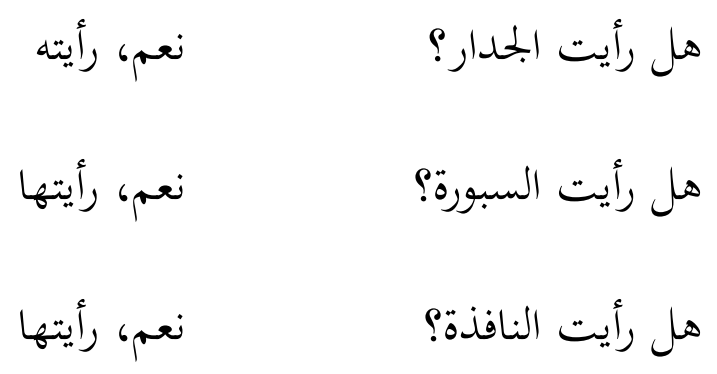

(3) Latihan Komunikatif

Latihan ini menumbuhkan daya kreasi siswa dan merupakan latihan berbahasa yang sebenarnya. Oleh karena itu, latihan ini sebaiknya diberikan apabila guru merasa bahwa siswa telah mendapatkan bahan yang cukup (berupa kosa-kata, struktur, dan ungkapan komunikatif) yang sesuai dengan situasi dan konteks yang ditentukan. 
Misalnya apabila siswa telah diberi contoh pola kalimat:

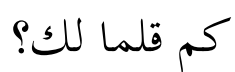

Maka guru bisa memberikan latihan kalimat jenis ini dengan meminta siswa untuk saling bertanya tentang keadaan sebenarnya dari mereka masing-masing.

Latihan-latihan komunikatif ini bisa dalam bentuk individual, dimana guru mengajukan pertanyaan-pertanyaan kepada siswa, misalnya:

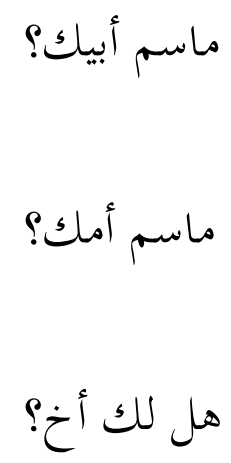

Kemudian latihan ini diterapkan berpasangan dan dalam kelompok kecil. Walaupun pola kalimat yang dilatih masih berkisar pada pola-pola tertentu, tetapi respon yang timbul mungkin tidak terduga-duga dan itulah yang dinamakan komunikasi yang sebenarnya. 


\section{REFERENSI}

Atha Ibn Khalil, Atha. 2000. Taisir Wushul Ila al-Wushul-Dirasat Fi Ushul al-Fiqh, cet. III,Dar Ummah -Beirut.

Effendy, Ahmad Fuad. 2005, Metodologi Pengajaran Bahasa Arab, Malang: Misykat.

Khouly, Muhammad Ali al. 1986. Asa:li:b Tadri:s al-Lughah al-Arabiyah. Riyadh:jami'at alImam Muhammad ibn Sa'ud

Musthafa al-Ghalayaini, Musthafa. 2005. Jami ad-Durus al-Arabiyah, Dar al-Hadits - alQahirah.

Ridho, Ali. 1986. Al Marja' fi allughoh al 'arobiyah fi nahwiha wa sharfiha. Juz 1. Beirut:Darul Fikri 